\title{
Role of Infection and Neurologic Dysfunction in Chronic Fatigue Syndrome
}

\section{Citation}

Komaroff, Anthony, and Tracey Cho. 2011. "Role of Infection and Neurologic Dysfunction in Chronic Fatigue Syndrome." Seminars in Neurology 31 (03) (July): 325-337. doi:10.1055/ s-0031-1287654.

\section{Published Version}

10.1055/s-0031-1287654

\section{Permanent link}

http://nrs.harvard.edu/urn-3:HUL.InstRepos:37156529

\section{Terms of Use}

This article was downloaded from Harvard University's DASH repository, and is made available under the terms and conditions applicable to Other Posted Material, as set forth at http:// nrs.harvard.edu/urn-3:HUL.InstRepos:dash.current.terms-of-use\#LAA

\section{Share Your Story}

The Harvard community has made this article openly available.

Please share how this access benefits you. Submit a story.

\section{Accessibility}




\title{
Role of Infection and Neurologic Dysfunction in Chronic Fatigue Syndrome
}

\author{
Anthony L. Komaroff, M.D., ${ }^{1,3}$ and Tracey A. Cho, M.D. ${ }^{2,3,4}$
}

Chronic fatiguing illnesses following well-documented infections and acute "infectious-like" illnesses of uncertain cause have been reported for many decades. Chronic fatigue syndrome (CFS) was first formally defined in 1988. There is considerable evidence that CFS is associated with abnormalities of the central and autonomic nervous systems. There also is evidence linking several infectious agents with CFS, although no agent has been proven to be a cause of the illness. Most of the infectious agents that have been linked to CFS are able to produce a persistent, often life-long, infection and thus are a constant incitement to the immune system. Most also have been shown to be neuropathogens. The evidence is consistent with the hypothesis that CFS, in some cases, can be triggered and perpetuated by several chronic infections that directly or indirectly affect the nervous system, and that symptoms are a reflection of the immune response to the infection.

KEYWORDS: Chronic fatigue syndrome, neuroendocrine, magnetic resonance imaging, central nervous system, autonomic nervous system, depression, immune activation, mitochondrial dysfunction, Epstein-Barr virus, human herpesvirus 6, enterovirus

Chronic fatigue syndrome (CFS) is a chronic illness defined entirely by a constellation of symptoms, including profound fatigue, impaired memory and concentration, headaches, muscle and joint pain, and postexertional malaise. ${ }^{1}$ Between 1 and 8 in 1000 adults in the United States meet the Centers for Disease Control and Prevention (CDC) criteria for the syndrome; ${ }^{2}$ it occurs in all age, ethnic, and socioeconomic groups. Patients with CFS report substantial functional impairment $^{3}$ and cost the U.S. economy approximately $\$ 9$ billion annually in lost productivity. ${ }^{4}$

There is no proof that any infectious agent causes CFS, yet there is considerable evidence linking infectious agents with CFS. There also is considerable evidence that the nervous system is involved in the pathogenesis of CFS, although there is no proof of this hypothesis. In this review, we will expand on both of these propositions.

\section{CHRONIC FATIGUE SYNDROME AND THE NERVOUS SYSTEM}

\section{Evidence of Central Nervous System Involvement}

In an illness characterized by fatigue, pain, and cognitive problems, it is reasonable to postulate that the central nervous system (CNS) is directly or indirectly involved.

\footnotetext{
${ }^{1}$ Division of General Medicine, Department of Medicine, Brigham and Women's Hospital; ${ }^{2}$ Department of Neurology, Massachusetts General Hospital; ${ }^{3}$ Department of Neurology, Brigham and Women's Hospital; ${ }^{4}$ Harvard Medical School, Boston, Massachusetts.

Address for correspondence and reprint requests: Anthony L. Komaroff, M.D., Harvard Medical School, 10 Shattuck Street, 2nd Floor, Boston, MA 02115 (e-mail: Komaroff@hms.harvard.edu).
}

Emerging and Controversial Issues in Neurology: Infectious Diseases; Guest Editor, Tracey A. Cho, M.D.

Semin Neurol 2011;31:325-337. Copyright (C) 2011 by Thieme Medical Publishers, Inc., 333 Seventh Avenue, New York, NY 10001, USA. Tel: $+1(212)$ 584-4662.

DOI: http://dx.doi.org/10.1055/s-0031-1287654.

ISSN 0271-8235. 
Indeed, many studies of the CNS have compared patients with CFS to healthy controls and controls with other fatiguing illnesses.

\section{NEUROENDOCRINE STUDIES}

Multiple studies have demonstrated hypofunction of corticotropin-releasing $(\mathrm{CRH})$ neurons in the hypothalamus, ${ }^{5}$ and hypocortisolism (distinct from Addison disease). ${ }^{6-10}$ This downregulation of the hypothalamicpituitary-adrenal (HPA) axis in CFS stands in contrast to the upregulation seen in major depression. Serotonergic and noradrenergic hypothalamic pathways, ${ }^{11-13}$ and growth hormone secretion ${ }^{14}$ also are disrupted. One possible cause of hypothalamic dysfunction and fatigue is the production of cytokines produced in response to a chronic infection of the CNS. ${ }^{15-18}$

\section{MAGNETIC RESONANCE IMAGING}

The preponderance of published studies have found areas of high signal on T2-weighted magnetic resonance imaging (MRI) in patients with CFS at a higher frequency than in age- and gender-matched healthy control volunteers. ${ }^{19-22}$ Most often, the areas of high signal are small and punctate, and are located in the subcortical white matter. These abnormalities may be more likely in CFS patients who have no concomitant psychiatric illness. ${ }^{23}$ Studies using MRI also have found enlarged ventricles ${ }^{24}$ and reduced gray matter volume. ${ }^{25,26}$ One group assessed MRI findings and functional capacity at the same point in time, and found a strong association between the two: CFS patients with more MRI abnormalities were also more functionally impaired, suggesting that the MRI findings had clinical relevance. ${ }^{22}$ These findings were not confirmed by other investigators, although the small number of patients made possible a type 2 error. $^{27}$

\section{FUNCTIONAL MRI (fMRI)}

Functional MRI (fMRI) of CFS patients compared with matched healthy control volunteers reportedly reveals abnormalities. When given motor and visual imagery tasks, patients with CFS demonstrated reduced striatal and ventral cingulate activation and greater visual system activation than control volunteers. ${ }^{28}$ Responsiveness of the auditory cortex to a task-independent stimulus (sound) was delayed and impaired in patients with CFS when engaged in a fatigue-inducing task (visual), and the degree of delay correlated with the patients' report of fatigue severity. ${ }^{29}$ Although patients with CFS performed comparably to matched control volunteers on tasks of verbal working memory, fMRI revealed considerably greater activation of working memory networks in the CFS patients. As the intensity of the cognitive challenge increased, the difference between cases and controls was amplified. ${ }^{30}$
Similar findings with a different cognitive challenge have been reported by others. ${ }^{31-33}$

\section{IN VIVO MAGNETIC RESONANCE SPECTROSCOPY OF BRAIN}

Proton magnetic resonance spectroscopy (MRS) has revealed significantly reduced concentration of $\mathrm{N}$-acetylaspartate in the hippocampus of patients with CFS, compared with healthy control volunteers, a result thought likely to reflect reduced metabolism of neurons or glial cells. ${ }^{34}$ Using the same technology, other investigators have found a highly significant increase in the spectra from choline-containing compounds in CFS patients. This result may be due to higher cell membrane turnover secondary to injury. ${ }^{35,36}$

\section{SINGLE PHOTON EMISSION COMPUTED TOMOGRAPHY AND POSITRON EMISSION TOMOGRAPHY}

Studies comparing patients with CFS to age- and gender-matched healthy control volunteers have found single photon emission computed tomography (SPECT) abnormalities that could represent either hypoperfusion in the microcirculation and/or metabolic dysfunction of neuronal and glial cells. ${ }^{20,37-39}$ Other investigators have not reported similar findings. ${ }^{40,41}$ Similar abnormalities have been reported in patients with CFS using positron emission tomography (PET), ${ }^{42,43}$ findings not present in a comparison group with major depression. ${ }^{44} \mathrm{PET}$ also has revealed reduction of serotonin transporters in the anterior cingulate ${ }^{43}$ and hippocampus. ${ }^{45}$

\section{ELECTROENCEPHALOGRAPHY}

Motor cortex excitability has been reported in chronic fatigue syndrome. ${ }^{46}$ Spectral analysis of EEG electroencephalography (EEG) data has been reported to produce a pattern that distinguishes patients with CFS from healthy and depressed control volunteers. ${ }^{47}$ Other investigators have identified several significant differences during motor performance in spectrum analysis and motor activity-related cortical potentials. ${ }^{48}$

\section{SPINAL FLUID STUDIES}

A small study found that patients with CFS were significantly more likely than healthy control volunteers to have elevated levels of protein or pleocytosis. ${ }^{49}$ Nuclear magnetic spectroscopy has revealed increased lactate levels in ventricular spinal fluid in patients with CFS, compared with healthy control volunteers and control volunteers with generalized anxiety disorder and major depression. ${ }^{50,51}$ The results of the study, including patients with major depression, did not reach statistical significance, but the number of study participants was small. Finally, a study employing liquid chromatography, mass spectrometry, and peptide sequencing of spinal fluid from patients with CFS 
found a group of proteins ("a proteomic signature" of CFS) that distinguished patients with CFS from healthy control volunteers. ${ }^{52}$ The findings were replicated in a small independent second cohort of patients with CFS.

\section{PAIN}

Mechanisms of pain have not been studied extensively in CFS, but they have been in a very similar syndrome, fibromyalgia. The hyperalgesia and allodynia that are so frequently reported by patients with CFS and fibromyalgia may be due to central sensitization or augmented sensory processing. ${ }^{53}$

\section{COGNITION}

Neuropsychological testing of cognition has revealed abnormalities in patients with CFS, ${ }^{54-67}$ abnormalities not explained by a coexisting depression. ${ }^{56} \mathrm{~A}$ recent meta-analysis of 50 eligible studies found deficits primarily in attention, memory and reaction time, and not in fine motor speed, vocabulary, or reasoning. ${ }^{68}$ Another recent study directly compared cognitive function in 25 patients with CFS, 25 with major depression and 25 healthy control volunteers. Patients with CFS were found to have impairments in attention and visual and verbal episodic memory; these deficits were not found in the comparison groups. ${ }^{69}$

\section{Evidence of Autonomic Involvement}

Abnormalities of autonomic function in adults and children have been reported by multiple investigators. ${ }^{70-80}$ A consensus panel of autonomic experts concluded that the literature provided strong evidence for exaggerated venous pooling, diminished red cell mass, reduced plasma volume, disordered sympathetic activity, impaired baroreflex function, and reduced cerebral perfusion. ${ }^{80,81}$ The most frequently observed disorders on autonomic testing are postural orthostatic tachycardia syndrome, neurally mediated hypotension, and heart rate variability during head-up tilt testing. Investigators have reported a strong correlation between symptoms of autonomic dysfunction, as assessed by the Composite Autonomic Symptom Scale (COMPASS), and fatigue, as assessed by a validated instrument, the Fatigue Impact Scale. ${ }^{82}$

\section{Is Chronic Fatigue Syndrome a Psychiatric Illness?}

Depression may be the most common cause of the presenting complaint of fatigue. Thus, the role of psychiatric illness in CFS has been debated. Most studies have found that in 30 to $50 \%$ of patients with CFS there is no co-existing psychiatric disorder, and that most of those with a psychiatric disorder developed the disorder only after becoming ill with CFS. ${ }^{83-87}$ In addition, a controlled trial of fluoxetine showed no improvement in fatigue in patients with CFS, including those with a concomitant major depression. ${ }^{88}$ Clauw notes the evolution of thinking on this issue: "Investigators who once staunchly viewed CFS as a psychiatric condition have significantly tempered their views, now acknowledging that these conditions are clearly separable from, and often occur independently of, psychiatric disorders." 53

\section{CHRONIC FATIGUE SYNDROME AND INFECTION}

\section{Epidemiologic Studies}

Postinfectious fatigue syndromes have been described in the literature over the past 70 years. Sometimes these syndromes have followed well-documented specific acute viral and bacterial infections, ${ }^{89-94}$ and sometimes they have followed acute syndromes with symptoms suggesting infection, such as fever, myalgias, respiratory, and gastroenterologic symptoms. ${ }^{95,96}$

Hickie and colleagues reported a prospective observational study that confirmed the existence of a postinfectious fatigue syndrome. ${ }^{97}$ The study was conducted in a small, rural Australian town. Virtually all medical care in the community was provided by a small number of health professionals and facilities. This meticulously conducted study identified all cases of acute infection with Epstein-Barr virus (a DNA virus), Ross River virus (an RNA virus), and Coxiella burnetii (the intracellular bacterium that causes $\mathrm{Q}$ fever) during a predefined window of time. Of the 253 patients in the study, $12 \%$ of patients developed a postinfectious fatigue syndrome 6 months after their acute infection. Virtually all the patients met the CDC criteria for CFS. The progression and regression of symptoms was quite similar regardless of the infectious agent. Chronic fatigue syndrome was more likely to develop in patients with more severe acute infectious symptoms, and was not more likely to occur in those with premorbid psychological problems. ${ }^{98,99}$ The presence of more severe acute infectious symptoms was correlated with increased production of proinflammatory cytokines in blood. ${ }^{98}$ This increased production of cytokines did not persist 6 to 12 months later, when cytokine levels were comparable between the patients who developed CFS and those who did not, suggesting that infection may have initiated the disease process but may not be perpetuating it. ${ }^{100}$

\section{Immunologic Studies}

Although not all published studies concur, the preponderance of the published literature indicates that patients 
with CFS have increased numbers of CD8 + cytotoxic $\mathrm{T}$ cells that bear antigenic markers of activation on their cell surface. ${ }^{101}$

Most published studies have found an increased production of various proinflammatory cytokines ${ }^{15-17,102-}$ ${ }^{106}$ and type 2 cytokine-producing cells ${ }^{107}$ in the blood. A recent analysis of cytokine networks in patients with CFS, compared with healthy control volunteers, found an enhanced $\mathrm{T}_{\mathrm{H}} 2$ milieu. ${ }^{108}$ Proinflammatory cytokines can produce symptoms characteristic of CFS-fatigue, fevers, adenopathy, myalgias, arthralgias, sleep disorders, cognitive impairment, and mood disorders-whether produced in the periphery (and penetrating a porous blood-brain barrier) or produced by an inflammatory process in the CNS. There have been few studies on cerebrospinal fluid (CSF) to pursue this possibility.

Additionally, an important arm of the antiviral immune response, function of natural killer cells, is impaired in patients with CFS. ${ }^{108-113}$ These observations are similar to those seen in patients with welldocumented latent viral infections. ${ }^{108}$

The 2-5A synthetase/ RNase L enzymatic pathway in lymphocytes (the $2-5 \mathrm{~A}$ pathway), which is induced by viral infection, is activated in CFS, and a characteristic low-molecular-weight form of RNase $\mathrm{L}$ is produced. ${ }^{114-116}$

Finally, gene expression studies using microarray technology from different laboratories, studying different groups of patients, find changes indicating a state of chronic activation of the immune system. ${ }^{117-122}$ Collectively, these studies suggest, but do not prove, that there may be an underlying chronic infectious process in some patients with CFS.

\section{Evidence of Mitochondrial Dysfunction, Oxidative and Nitrosative Stress}

Several studies of muscle mitochondria have found what appear to be acquired abnormalities in patients with CFS. ${ }^{123-126}$ Gene expression studies have also found altered expression of genes involved in mitochondrial function in cases of postinfectious fatigue caused by Epstein-Barr virus. ${ }^{127}$

Studies of blood and muscle demonstrate increased oxidative stress, as evidenced by increased levels of isoprostanes and oxidized LDL cholesterol, ${ }^{128}$ reduced levels of antioxidants, ${ }^{129}$ increased levels of peroxides and superoxides, ${ }^{130}$ and decreased levels of $\alpha$ tochopherol. ${ }^{131} \mathrm{~A}$ study employing in vivo proton MR spectroscopy found evidence of cerebral oxidative stress. ${ }^{132}$ Longitudinal studies suggest that oxidative stress is greatest at times of clinical exacerbation. ${ }^{133}$ Similarly, increased levels of nitric oxide, nitrate, and peroxynitrite demonstrated in patients with CFS is evidence of increased nitrosative stress. ${ }^{134}$ Strikingly increased lactate levels in CSF indicate increased anae- robic metabolism in the CNS, consistent with mitochondrial dysfunction. ${ }^{50,51}$ Finally, increased production of iNOS, COX-2, and of NFKB have been reported in the blood of patients with CFS. ${ }^{135,136}$

Several studies have found that exercise precipitates oxidative stress in patients with CFS, in contrast to healthy and disease control groups. Nitric oxide metabolite production in blood reportedly rises nearly fivefold in patients, but does not rise in controls. ${ }^{137}$ One group compared patients with CFS to healthy control volunteers following a sustained moderate exercise task. $\mathrm{Pa}$ tients with CFS had much higher expression of genes for receptors important in sensing metabolites that mediate muscle fatigue and pain than the control volunteers. ${ }^{138} \mathrm{~A}$ controlled study comparing patients with CFS to sedentary healthy control volunteers during two types of controlled exercise (submaximal, and self-paced physiologically limited) found that pain thresholds following exercise increased in controls, but decreased in patients with CFS. ${ }^{139}$ These studies suggest, but do not prove, a physiologic basis for the postexertional malaise reported by a high fraction of patients with CFS.

An intriguing model has been proposed by Maes ${ }^{135,136}$ and others, and is summarized in Fig. 1. In patients with CFS, a series of vicious metabolic cycles may exist involving inflammation, oxidative and nitrosative stress, mitochondrial dysfunction, and possibly cell death; the inflammation is triggered by mitochondrial fragments entering the circulation. ${ }^{140}$ At the core of these vicious cycles are mitochondrial dysfunction and increased production of $\mathrm{NF \kappa B}$ - both of which are commonly caused by infection. Oxidative damage is prominent in viral infections of the nervous system. ${ }^{141}$ However, when it comes to incriminating infectious agents in CFS, this is all no more than circumstantial evidence.

\section{Studies of Specific Infectious Agents}

\section{EPSTEIN-BARR VIRUS}

Fatigue states following acute infectious mononucleosis, an illness typically caused by Epstein-Barr virus (EBV), have been reported for over 60 years, ${ }^{142}$ and recently have been well documented. ${ }^{143,144}$ Interest in CFS became resurgent in the mid-1980s due to several publications linking high titers of antibodies to EBV with a chronic, fatiguing illness. ${ }^{145,146}$ Subsequent studies have often, but not always, found higher titers of two EBV antibodies-viral capsid antigen-IgG and early antigen-IgG. However, over $90 \%$ of adults in the United States are chronically infected with EBV, and therefore seropositive. Higher levels of antibodies to EBV could be a secondary reflection of subtle primary immune dysfunction in CFS, and do not necessarily indicate an etiologic role for $\mathrm{EBV}$ in $\mathrm{CFS}$. 


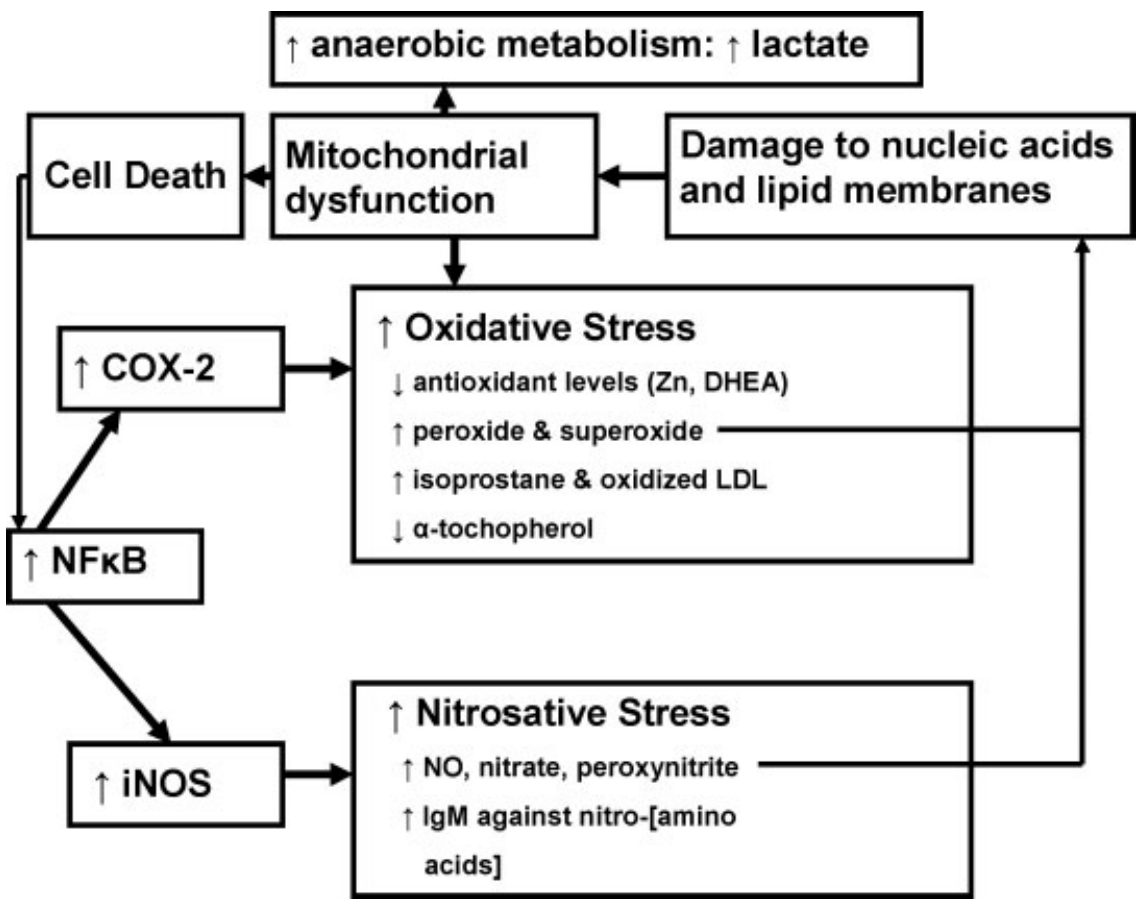

Figure 1 Possible metabolic vicious cycles in chronic fatigue syndrome. Inflammation is triggered by the transcription factor $N F_{\kappa} B$, stimulating the production of COX-2 and iNOS. Oxidative and nitrosative stress results, leading to damage of lipid membranes and nucleic acids, and possibly to cell death. Mitochondrial DNA damage leads to mitochondrial dysfunction, which encourages more oxidative stress, and to anaerobic metabolism. Cell death leads to mitochondrial fragments entering the circulation, which in turn triggers the production of $\mathrm{NF \kappa B}$ and further oxidative and nitrosative stress.

\section{HUMAN HERPESVIRUS-6}

First discovered in 1986 in the laboratory of Robert Gallo, ${ }^{147}$ the virus now called human herpesvirus-6 (HHV-6) also has been linked with CFS. Like its cousin herpesvirus EBV, HHV-6 permanently infects nearly $90 \%$ of the human race. Thus, as with EBV, most people are seropositive.

Unlike EBV, the evidence linking HHV-6 to CFS does not rely on antibody levels to viral antigens. The first large study to suggest a link included 259 patients with a CFS-like illness (the case definition had not yet been developed). Primary culture of $1 \mathrm{ym}^{-}$ phocytes showed active replication of HHV-6 in 70\% of the patients in contrast to $20 \%$ of the age- and gendermatched healthy control volunteers $\left(p<10^{-8}\right) .{ }^{19}$

Many studies that have employed assays that can detect active infection-polymerase chain reaction (PCR) of serum or plasma, IgM early antigen antibodies, and primary cell culture-have found an association between CFS and active HHV-6 infection. ${ }^{19,148-154}$ Several other studies have not demonstrated this association. ${ }^{155,156}$

The greater frequency of reactivated infection with HHV-6 more often in patients with CFS in comparison to healthy control volunteers does not prove an etiologic role for this virus. As with EBV, a primary condition that led to subtle immune dysfunction could encourage reactivation of latent HHV-6 infection.
Nevertheless, HHV-6 is a plausible candidate to cause some cases of CFS. A recent review summarizes the evidence suggesting that HHV-6 is a CNS pathogen ${ }^{157}$ associated with multiple sclerosis, mesial temporal lobe epilepsy, encephalitis in both immunosuppressed and immunocompetent individuals, and febrile seizures in children. The review also discusses the capacity of HHV-6 to infect multiple types of glial cells, and to induce potentially destructive immune responses. As a potent inducer of TNF- $\alpha$ and IL-1B, ${ }^{158}$ and IL- $6,{ }^{159-}$ 162 the virus could produce CNS infection directly following primary infection, and achieve latency there, or it could traverse the blood-brain barrier, leading to the production of inflammatory cytokines in the CNS.

\section{XMRV AND POLYTROPIC MURINE LEUKEMIA VIRUSES}

Xenotropic murine leukemia virus-related virus (XMRV) was first identified in prostate cancer specimens, although not all investigators have corroborated the initial finding. ${ }^{163}$ Recently, a multiinstitutional team reported a strong association of this virus with CFS. They detected viral nucleic acids by PCR in $67 \%$ of patients compared with $4 \%$ of healthy blood donors. ${ }^{164}$ These investigators also reported finding antibodies to the virus in serum, and viral antigens in peripheral mononuclear cells. Additionally, the virus was isolated from both the plasma and from peripheral mononuclear cells on co-cultivation with a reportedly infection-free 
cell line (called LNCaP cells) known to permit XMRV infection. These additional studies were performed on only a small fraction of the total patients, however.

Another group of investigators reported that it had identified nucleic acids not from XMRV, but from a related family of viruses, the polytropic murine leukemia viruses (MLVs) in 87\% of 37 CFS patients and 7\% of 44 healthy blood-donor controls. ${ }^{165}$ By several measures, including a highly sensitive assay for mouse mitochondrial DNA, the team argued that the PCR results were not falsely positive due to contamination with mouse DNA.

However, as of the time of publication, many other groups have not been able to confirm the association, ${ }^{166-168}$ including in patients that previously had tested as positive for XMRV. ${ }^{167}$ Moreover, XMRV may be a contaminant of commercial reagents. ${ }^{167}$ Whether these murine viruses are associated with CFS remains uncertain. The National Institutes of Health has launched studies to develop sensitive and reproducible assays for these viruses, and a multicenter study to look for the viruses in patients with CFS, including patients previously found to be positive by the two laboratories. ${ }^{164,165}$ Hopefully, these studies will resolve the uncertainty as to whether mouse retroviruses are associated with CFS.

\section{ENTEROVIRAL INFECTION}

Several epidemics in different countries of an apparently infectious illness followed by months or years of fatigue were studied in the mid- $20^{\text {th }}$ century. Investigators initially suspected that they were atypical epidemics of poliovirus (an enterovirus). ${ }^{96}$ Because of their tropism for the nervous system, enteroviruses have long been suspected as etiologic agents in postinfectious fatigue syndromes. Several investigators have reported enteroviral involvement in some cases of CFS. ${ }^{169-176}$ The most provocative recent report involved 165 consecutive patients with CFS accompanied by prominent gastrointestinal symptoms. Each of them had biopsies of the gastric antrum, as did 34 control volunteers without CFS. The enteroviral antigen VP1 was found in $82 \%$ of the CFS patients versus $20 \%$ of the controls. Enteroviral RNA was found in $37 \%$ of the CFS patients versus $5 \%$ of controls. ${ }^{176}$ In five patient samples, transient growth of noncytopathic enteroviruses was noted. None of the samples from patients or controls were positive for antigens from a "control" enteric pathogen, cytomegalovirus. No report from another group attempting to replicate these findings has yet been reported. Some investigators have been unable to link enteroviruses to CFS through studies of blood and stool. ${ }^{177,178}$

\section{PARVOVIRUS}

The development of CFS following well-documented acute infection with parvovirus B19 has been re- ported. ${ }^{179-181}$ One study involved 200 patients with CFS and 200 normal blood donor control volunteers. There were no differences in the frequency of $\mathrm{IgG}$ or IgM antibodies to structural proteins, but $42 \%$ of the CFS patients versus $7 \%$ of controls had IgG antibodies to the nonstructural protein, NS1, a marker associated with chronic and severe parvovirus infection. ${ }^{182}$

\section{BACTERIAL INFECTIONS}

There are cases of a chronic fatiguing illness that develop in the wake of well-documented, and appropriately treated cases of Lyme disease, in which the cardinal manifestations of Lyme disease (e.g., arthritis, carditis) have resolved. ${ }^{183,184}$ However, even among patients with CFS who live in areas endemic for Lyme disease, this bacterial infection is an unusual cause of CFS. ${ }^{185}$

A condition very similar to CFS has been described following $\mathrm{Q}$ fever, and is associated with the persistence of bacterial antigen. ${ }^{186,187}$ Cytokine dysregulation has been reported in these patients and could explain the symptoms. ${ }^{188}$

\section{EVALUATION OF PATIENTS WITH POSSIBLE CFS}

Clinical evaluation of a patient with protracted and severe fatigue, who may have CFS, requires both assessing the possibility of other chronic, fatiguing illnessesincluding multiple sclerosis, systemic lupus erythematosus, and many others-as well as verifying the presence of those symptoms that constitute the CDC case definition of CFS.

It is our clinical impression-not tested in a blinded, controlled study involving non-CFS control volunteers-that patients with CFS are more likely to have the following abnormalities on examination: posterior cervical and posterior auricular adenopathy, persistent tachycardia when moving from a recumbent to a standing position, impaired tandem gait, and abnormal Romberg test.

Although as summarized above, many laboratory and imaging tests have revealed abnormalities that are more common in patients with CFS than in various healthy control and disease comparison groups, none of these tests has sufficient specificity and sensitivity to constitute a diagnostic test. A panel convened at NIH recommended a small and inexpensive battery of laboratory tests in patients with protracted and severe fatigue, primarily to rule out other causes of fatigue: complete blood count with manual differential white blood cell count, erythrocyte sedimentation rate, chemistry panel, urinalysis, and thyroid function testing. ${ }^{189}$ Based on a case-control study that we conducted involving over 700 cases and controls over 10 years in two different geographic areas, the following test abnormalities may be found more often in patients with CFS: 
atypical lymphocytosis, circulating immune complexes, elevated levels of $\mathrm{IgG}$, and antinuclear antibodies. ${ }^{190} \mathrm{As}$ patients with severe and prolonged fatigue who live in areas endemic for Lyme disease nevertheless rarely have positive serology, in the absence of Lyme-specific symptoms and signs, we do not recommend routine testing for Lyme disease. ${ }^{185}$

\section{FUTURE DIRECTIONS FOR THE STUDY OF CFS}

The symptom constellation of fatigue, concentration/ memory problems, headache, and generalized weakness is familiar to any neurologic practice. These symptoms are commonly seen in primary CNS diseases, such as multiple sclerosis; systemic diseases with secondary impact on the CNS, such as infectious mononucleosis; and in primary psychiatric diseases, such as depression. ${ }^{191}$ These symptoms may also occur independently of these diseases in CFS. A first step for the neurologist is to acknowledge that the syndrome of CFS can occur in the absence of psychiatric illness or malingering. The evidence suggests that objective changes occur in the CNS in the context of CFS and are distinct from depression alone. We recognize that many challenges remain in terms of defining the nature of the correlation (causality) and the specificity of the changes to CFS.

T2-weighted MRI changes and metabolic patterns on fMRI, MRS, and SPECT functional connectivity $\mathrm{MRI}^{192}$ may help clarify specific CNS abnormalities in CFS, help study the natural history of CFS, and provide tools for assessing response to treatment. Connecting these radiographic changes to underlying pathologic processes will remain a challenge, however, as the non-life-threatening severity of illness and lack of focal localization within the brain preclude routine studies of antemortem or postmortem brain tissue. Developments in molecular imaging may eventually help bridge this gap by allowing more specific imaging of affected brain tissue at the molecular and cellular level. The coupling of reporter molecules to cells, enzymes, or genes of interest could theoretically be applied to CFS to assess specific pathologic processes that alter brain function in $\mathrm{CSF}^{193-195}$

In addition to further refinement of neuroimaging, further technologic advances in virology, immunology, and genetics may elucidate the underlying mechanisms through which infection, immune response, and genetic predisposition converge in CSF. As described by Wilson and Tyler (this issue), MassTag PCR, DNA microarrays, and high-throughput DNA pyrosequencing may identify viral pathogens in encephalitis and other CNS syndromes where conventional technologies have failed.

Further research should incorporate formal neuropsychological testing, neuroimaging, and immuno- logic markers over longer periods to distinguish those changes that are specific to CFS as opposed to other evolving diagnoses, and to define which changes are dynamic. As with other diseases without a well-defined pathologic etiology, such as multiple sclerosis, there may be multiple underlying triggers of an inflammatory process, which in certain susceptible individuals leads to the clinical manifestations of CFS. By building on the evidence we have summarized here, our hope is that ongoing research will lead to a better understanding of CFS and thus to more effective treatment or even prevention of this debilitating disorder.

\section{ACKNOWLEDGMENTS}

The authors thank Jessica Erickson for her help in surveying the literature and editing the manuscript. A.L.K. received support from the DeYoung Foundation.

\section{REFERENCES}

1. Fukuda K, Straus SE, Hickie I, Sharpe MC, Dobbins JG, Komaroff A; International Chronic Fatigue Syndrome Study Group. The chronic fatigue syndrome: a comprehensive approach to its definition and study. Ann Intern Med 1994;121(12):953-959

2. Reyes M, Nisenbaum R, Hoaglin DC, et al. Prevalence and incidence of chronic fatigue syndrome in Wichita, Kansas. Arch Intern Med 2003;163(13):1530-1536

3. Komaroff AL, Fagioli LR, Doolittle TH, et al. Health status in patients with chronic fatigue syndrome and in general population and disease comparison groups. Am J Med 1996;101(3):281-290

4. Reynolds KJ, Vernon SD, Bouchery E, Reeves WC. The economic impact of chronic fatigue syndrome. Cost Eff Resour Alloc 2004;2(1):4

5. Demitrack MA, Dale JK, Straus SE, et al. Evidence for impaired activation of the hypothalamic-pituitary-adrenal axis in patients with chronic fatigue syndrome. J Clin Endocrinol Metab 1991;73(6):1224-1234

6. Dinan TG, Majeed T, Lavelle E, Scott LV, Berti C, Behan $\mathrm{P}$. Blunted serotonin-mediated activation of the hypothalamic-pituitary-adrenal axis in chronic fatigue syndrome. Psychoneuroendocrinology 1997;22(4):261-267

7. Scott LV, Medbak S, Dinan TG. The low dose ACTH test in chronic fatigue syndrome and in health. Clin Endocrinol (Oxf) 1998;48(6):733-737

8. Scott LV, Dinan TG. Urinary free cortisol excretion in chronic fatigue syndrome, major depression and in healthy volunteers. J Affect Disord 1998;47(1-3):49-54

9. Scott LV, Teh J, Reznek R, Martin A, Sohaib A, Dinan TG. Small adrenal glands in chronic fatigue syndrome: a preliminary computer tomography study. Psychoneuroendocrinology 1999;24(7):759-768

10. Cleare AJ, Blair D, Chambers S, Wessely S. Urinary free cortisol in chronic fatigue syndrome. Am J Psychiatry 2001; 158(4):641-643

11. Demitrack MA, Gold PW, Dale JK, Krahn DD, Kling MA, Straus SE. Plasma and cerebrospinal fluid monoamine metabolism in patients with chronic fatigue syndrome: 
preliminary findings. Biol Psychiatry 1992;32(12):10651077

12. Bakheit AMO, Behan PO, Dinan TG, Gray CE, O'Keane V. Possible upregulation of hypothalamic 5-hydroxytryptamine receptors in patients with postviral fatigue syndrome. BMJ 1992;304(6833):1010-1012

13. Cleare AJ, Bearn J, Allain T, et al. Contrasting neuroendocrine responses in depression and chronic fatigue syndrome. J Affect Disord 1995;34(4):283-289

14. Moorkens G, Berwaerts J, Wynants H, Abs R. Characterization of pituitary function with emphasis on $\mathrm{GH}$ secretion in the chronic fatigue syndrome. Clin Endocrinol (Oxf) 2000;53(1):99-106

15. Patarca R. Cytokines and chronic fatigue syndrome. Ann N Y Acad Sci 2001;933:185-200

16. Gupta S, Aggarwal S, Starr A. Increased production of interleukin- 6 by adherent and non-adherent mononuclear cells during 'natural fatigue' but not following 'experimental fatigue' in patients with chronic fatigue syndrome. Int J Mol Med 1999;3(2):209-213

17. Gupta S, Aggarwal S, See DM, Starr A. Cytokine production by adherent and non-adherent mononuclear cells in chronic fatigue syndrome. J Psychiatr Res 1997;31(1):149-156

18. Vgontzas AN, Zoumakis M, Papanicolaou DA, et al. Chronic insomnia is associated with a shift of interleukin-6 and tumor necrosis factor secretion from nighttime to daytime. Metabolism 2002;51(7):887-892

19. Buchwald D, Cheney PR, Peterson DL, et al. A chronic illness characterized by fatigue, neurologic and immunologic disorders, and active human herpesvirus type 6 infection. Ann Intern Med 1992;116(2):103-113

20. Schwartz RB, Garada BM, Komaroff AL, et al. Detection of intracranial abnormalities in patients with chronic fatigue syndrome: comparison of MR imaging and SPECT. AJR Am J Roentgenol 1994;162(4):935-941

21. Natelson BH, Cohen JM, Brassloff I, Lee HJ. A controlled study of brain magnetic resonance imaging in patients with the chronic fatigue syndrome. J Neurol Sci 1993;120(2): 213-217

22. Cook DB, Lange G, DeLuca J, Natelson BH. Relationship of brain MRI abnormalities and physical functional status in chronic fatigue syndrome. Int J Neurosci 2001;107(1-2):1-6

23. Lange G, DeLuca J, Maldjian JA, Lee H-J, Tiersky LA, Natelson BH. Brain MRI abnormalities exist in a subset of patients with chronic fatigue syndrome. J Neurol Sci 1999; 171(1):3-7

24. Lange G, Holodny AI, DeLuca J, et al. Quantitative assessment of cerebral ventricular volumes in chronic fatigue syndrome. Appl Neuropsychol 2001;8(1):23-30

25. Okada T, Tanaka M, Kuratsune H, Watanabe Y, Sadato N. Mechanisms underlying fatigue: a voxel-based morphometric study of chronic fatigue syndrome. BMC Neurol 2004; 4:14-19

26. de Lange FP, Kalkman JS, Bleijenberg G, Hagoort P, van der Meer JWM, Toni I. Gray matter volume reduction in the chronic fatigue syndrome. Neuroimage 2005;26(3):777781

27. Perrin R, Embleton K, Pentreath VW, Jackson A. Longitudinal MRI shows no cerebral abnormality in chronic fatigue syndrome. Br J Radiol 2010;83(989):419-423

28. de Lange FP, Kalkman JS, Bleijenberg G, et al. Neural correlates of the chronic fatigue syndrome-an fMRI study. Brain 2004;127(Pt 9):1948-1957
29. Tanaka M, Sadato N, Okada T, et al. Reduced responsiveness is an essential feature of chronic fatigue syndrome: A fMRI study. BMC Neurol 2006;6:9-23

30. Caseras X, Mataix-Cols D, Giampietro V, et al. Probing the working memory system in chronic fatigue syndrome: a functional magnetic resonance imaging study using the nback task. Psychosom Med 2006;68(6):947-955

31. Cook DB, O'Connor PJ, Lange G, Steffener J. Functional neuroimaging correlates of mental fatigue induced by cognition among chronic fatigue syndrome patients and controls. Neuroimage 2007;36(1):108-122

32. Caseras X, Mataix-Cols D, Rimes KA, et al. The neural correlates of fatigue: an exploratory imaginal fatigue provocation study in chronic fatigue syndrome. Psychol Med 2008; 38(7):941-951

33. Lange G, Steffener J, Cook DB, et al. Objective evidence of cognitive complaints in chronic fatigue syndrome: a BOLD fMRI study of verbal working memory. Neuroimage 2005;26(2):513-524

34. Brooks JCW, Roberts N, Whitehouse G, Majeed T. Proton magnetic resonance spectroscopy and morphometry of the hippocampus in chronic fatigue syndrome. Br J Radiol 2000; 73(875):1206-1208

35. Puri BK, Counsell SJ, Zaman R, et al. Relative increase in choline in the occipital cortex in chronic fatigue syndrome. Acta Psychiatr Scand 2002;106(3):224-226

36. Chaudhuri A, Condon BR, Gow JW, Brennan D, Hadley DM. Proton magnetic resonance spectroscopy of basal ganglia in chronic fatigue syndrome. Neuroreport 2003;14(2): 225-228

37. Ichise M, Salit IE, Abbey SE, et al. Assessment of regional cerebral perfusion by $99 \mathrm{~T} \mathrm{~cm}-\mathrm{HMPAO}$ SPECT in chronic fatigue syndrome. Nucl Med Commun 1992;13(10):767772

38. Schwartz RB, Komaroff AL, Garada BM, et al. SPECT imaging of the brain: comparison of findings in patients with chronic fatigue syndrome, AIDS dementia complex, and major unipolar depression. AJR Am J Roentgenol 1994; 162(4):943-951

39. Schmaling KB, Lewis DH, Fiedelak JI, Mahurin R, Buchwald DS. Single-photon emission computerized tomography and neurocognitive function in patients with chronic fatigue syndrome. Psychosom Med 2003;65(1):129136

40. Fischler B, D'Haenen H, Cluydts R, et al. Comparison of 99m Tc HMPAO SPECT scan between chronic fatigue syndrome, major depression and healthy controls: an exploratory study of clinical correlates of regional cerebral blood flow. Neuropsychobiology 1996;34(4):175-183

41. Lewis DH, Mayberg HS, Fischer ME, et al. Monozygotic twins discordant for chronic fatigue syndrome: regional cerebral blood flow SPECT. Radiology 2001;219(3):766-773

42. Siessmeier T, Nix WA, Hardt J, Schreckenberger M, Egle UT, Bartenstein P. Observer independent analysis of cerebral glucose metabolism in patients with chronic fatigue syndrome. J Neurol Neurosurg Psychiatry 2003;74(7):922928

43. Yamamoto S, Ouchi $\mathrm{Y}$, Onoe $\mathrm{H}$, et al. Reduction of serotonin transporters of patients with chronic fatigue syndrome. Neuroreport 2004;15(17):2571-2574

44. Tirelli U, Chierichetti F, Tavio M, et al. Brain positron emission tomography (PET) in chronic fatigue syndrome: preliminary data. Am J Med 1998;105(3A):54S-58S 
45. Cleare AJ, Messa C, Rabiner EA, Grasby PM. Brain 5HT1A receptor binding in chronic fatigue syndrome measured using positron emission tomography and [11C]WAY-100635. Biol Psychiatry 2005;57(3):239-246

46. Gordon R, Michalewski HJ, Nguyen T, Gupta S, Starr A. Cortical motor potential alterations in chronic fatigue syndrome. Int J Mol Med 1999;4(5):493-499

47. Duffy FH, McAnulty GB, McCreary MC, Cuchural GJ, Komaroff AL. EEG spectral coherence data distinguish chronic fatigue syndrome patients from healthy controls and depressed patients - A case control study. BMC Neurol 2011; 11(1):82

48. Siemionow V, Fang Y, Calabrese L, Sahgal V, Yue GH. Altered central nervous system signal during motor performance in chronic fatigue syndrome. Clin Neurophysiol 2004; 115(10):2372-2381

49. Natelson BH, Weaver SA, Tseng C-L, Ottenweller JE. Spinal fluid abnormalities in patients with chronic fatigue syndrome. Clin Diagn Lab Immunol 2005;12(1):52-55

50. Mathew SJ, Mao X, Keegan KA, et al. Ventricular cerebrospinal fluid lactate is increased in chronic fatigue syndrome compared with generalized anxiety disorder: an in vivo 3.0 T (1)H MRS imaging study. NMR Biomed 2009;22(3):251-258

51. Murrough JW, Mao X, Collins KA, et al. Increased ventricular lactate in chronic fatigue syndrome measured by $1 \mathrm{H}$ MRS imaging at $3.0 \mathrm{~T}$. II: comparison with major depressive disorder. NMR Biomed 2010;23(6):643-650

52. Baraniuk JN, Casado B, Maibach H, Clauw DJ, Pannell LK, Hess S. A chronic fatigue syndrome-related proteome in human cerebrospinal fluid. BMC Neurol 2005;5:22-40

53. Clauw DJ. Perspectives on fatigue from the study of chronic fatigue syndrome and related conditions. PM R 2010;2(5): 414-430

54. Johnson SK, DeLuca J, Fiedler N, Natelson BH. Cognitive functioning of patients with chronic fatigue syndrome. Clin Infect Dis 1994;18(Suppl 1):S84-S85

55. Krupp LB, Sliwinski M, Masur DM, Friedberg F, Coyle PK. Cognitive functioning and depression in patients with chronic fatigue syndrome and multiple sclerosis. Arch Neurol 1994; 51(7):705-710

56. Marcel B, Komaroff AL, Fagioli LR, Kornish RJ II, Albert MS. Cognitive deficits in patients with chronic fatigue syndrome. Biol Psychiatry 1996;40(6):535-541

57. Tiersky LA, Johnson SK, Lange G, Natelson BH, DeLuca J. Neuropsychology of chronic fatigue syndrome: a critical review. J Clin Exp Neuropsychol 1997;19(4):560-586

58. Daly E, Komaroff AL, Bloomingdale K, Wilson S, Albert MS. Neuropsychological function in patients with chronic fatigue syndrome, multiple sclerosis, and depression. Appl Neuropsychol 2001;8(1):12-22

59. Deluca J, Christodoulou C, Diamond BJ, Rosenstein ED, Kramer N, Natelson BH. Working memory deficits in chronic fatigue syndrome: differentiating between speed and accuracy of information processing. J Int Neuropsychol Soc 2004;10(1):101-109

60. DeLuca J, Johnson SK, Natelson BH. Information processing efficiency in chronic fatigue syndrome and multiple sclerosis. Arch Neurol 1993;50(3):301-304

61. Sandman CA, Barron JL, Nackoul K, Goldstein J, Fidler F. Memory deficits associated with chronic fatigue immune dysfunction syndrome. Biol Psychiatry 1993; 33(8-9):618-623
62. McDonald E, Cope H, David A. Cognitive impairment in patients with chronic fatigue: a preliminary study. J Neurol Neurosurg Psychiatry 1993;56(7):812-815

63. DeLuca J, Johnson SK, Natelson BH. Information processing efficiency in chronic fatigue syndrome and multiple sclerosis. Arch Neurol 1993;50(3):301-304

64. Schmaling KB, DiClementi JD, Cullum CM, Jones JF. Cognitive functioning in chronic fatigue syndrome and depression: a preliminary comparison. Psychosom Med 1994;56(5):383-388

65. DeLuca J, Johnson SK, Beldowicz D, Natelson BH. Neuropsychological impairments in chronic fatigue syndrome, multiple sclerosis, and depression. J Neurol Neurosurg Psychiatry 1995;58(1):38-43

66. DeLuca J, Johnson SK, Ellis SP, Natelson BH. Cognitive functioning is impaired in patients with chronic fatigue syndrome devoid of psychiatric disease. J Neurol Neurosurg Psychiatry 1997;62(2):151-155

67. Michiels V, Cluydts R, Fischler B. Attention and verbal learning in patients with chronic fatigue syndrome. J Int Neuropsychol Soc 1998;4(5):456-466

68. Cockshell SJ, Mathias JL. Cognitive functioning in chronic fatigue syndrome: a meta-analysis. Psychol Med 2010;40(8): 1253-1267

69. Constant EL, Adam S, Gillain B, Lambert M, Masquelier E, Seron X. Cognitive deficits in patients with chronic fatigue syndrome compared to those with major depressive disorder and healthy controls. Clin Neurol Neurosurg 2011;113(4):295-302

70. Sisto SA, Tapp W, Drastal S, et al. Vagal tone is reduced during paced breathing in patients with the chronic fatigue syndrome. Clin Auton Res 1995;5(3):139-143

71. Bou-Holaigah I, Rowe PC, Kan J, Calkins H. The relationship between neurally mediated hypotension and the chronic fatigue syndrome. JAMA 1995;274(12):961-967

72. Freeman R, Komaroff AL. Does the chronic fatigue syndrome involve the autonomic nervous system? Am J Med 1997;102(4):357-364

73. Stewart JM, Gewitz MH, Weldon A, Arlievsky N, Li K, Munoz J. Orthostatic intolerance in adolescent chronic fatigue syndrome. Pediatrics 1999;103(1):116-121

74. Stewart JM. Autonomic nervous system dysfunction in adolescents with postural orthostatic tachycardia syndrome and chronic fatigue syndrome is characterized by attenuated vagal baroreflex and potentiated sympathetic vasomotion. Pediatr Res 2000;48(2):218-226

75. Naschitz JE, Sabo E, Naschitz S, et al. Hemodynamic instability in chronic fatigue syndrome: indices and diagnostic significance. Semin Arthritis Rheum 2001;31(3):199-208

76. Naschitz JE, Sabo E, Naschitz S, et al. Fractal analysis and recurrence quantification analysis of heart rate and pulse transit time for diagnosing chronic fatigue syndrome. Clin Auton Res 2002;12(4):264-272

77. Peckerman A, LaManca JJ, Qureishi B, et al. Baroreceptor reflex and integrative stress responses in chronic fatigue syndrome. Psychosom Med 2003;65(5):889-895

78. Jones JF, Nicholson A, Nisenbaum R, et al. Orthostatic instability in a population-based study of chronic fatigue syndrome. Am J Med 2005;118(12):1415

79. Hollingsworth KG, Jones DE, Taylor R, Blamire AM, Newton JL. Impaired cardiovascular response to standing in chronic fatigue syndrome. Eur J Clin Invest 2010;40(7): 608-615 
80. Biswal B, Kunwar P, Natelson BH. Cerebral blood flow is reduced in chronic fatigue syndrome as assessed by arterial spin labeling. J Neurol Sci 2011;301(1-2):9-11

81. Gerrity TR, Bates J, Bell DS, et al. Chronic fatigue syndrome: what role does the autonomic nervous system play in the pathophysiology of this complex illness? Neuroimmunomodulation 2002-2003;10(3):134-141

82. Newton JL, Okonkwo O, Sutcliffe K, Seth A, Shin J, Jones DEJ. Symptoms of autonomic dysfunction in chronic fatigue syndrome. QJM 2007;100(8):519-526

83. Taerk GS, Toner BB, Salit IE, Garfinkel PE, Ozersky S. Depression in patients with neuromyasthenia (benign myalgic encephalomyelitis). Int J Psychiatry Med 1987;17(1):49-56

84. Kruesi MJP, Dale J, Straus SE. Psychiatric diagnoses in patients who have chronic fatigue syndrome. J Clin Psychiatry 1989;50(2):53-56

85. Wessely S, Powell R. Fatigue syndromes: a comparison of chronic "postviral" fatigue with neuromuscular and affective disorders. J Neurol Neurosurg Psychiatry 1989;52(8):940-948

86. Hickie I, Lloyd A, Wakefield D, Parker G. The psychiatric status of patients with the chronic fatigue syndrome. Br J Psychiatry 1990;156:534-540

87. Gold D, Bowden R, Sixbey J, et al. Chronic fatigue. A prospective clinical and virologic study. JAMA 1990; 264(1):48-53

88. Vercoulen JHMM, Swanink CMA, Zitman FG, et al. Randomised, double-blind, placebo-controlled study of fluoxetine in chronic fatigue syndrome. Lancet 1996; 347(9005):858-861

89. Benjamin JE, Hoyt RC. Disability following postvaccinal (yellow fever) hepatitis. JAMA 1945;128:319-324

90. Imboden JB, Canter A, Cluff LE. Convalescence from influenza. A study of the psychological and clinical determinants. Arch Intern Med 1961;108:393-399

91. Lawton AH, Rich TA, McLendon S, Gates EH, Bond JO. Follow-up studies of St. Louis encephalitis in Florida: reevaluation of the emotional and health status of the survivors five years after acute illness. South Med J 1970; 63(1):66-71

92. Rosene KA, Copass MK, Kastner LS, Nolan CM, Eschenbach DA. Persistent neuropsychological sequelae of toxic shock syndrome. Ann Intern Med 1982;96(6 Pt 2):865-870

93. Cluff LE, Trever RW, Imboden JB, Canter A. Brucellosis. II. Medical aspects of delayed convalescence. AMA Arch Intern Med 1959;103(3):398-405

94. Imboden JB, Canter A, Cluff LE, Trever RW. Brucellosis. III. Psychologic aspects of delayed convalescence. AMA Arch Intern Med 1959;103(3):406-414

95. Salit IE. Sporadic postinfectious neuromyasthenia. CMAJ 1985;133(7):659-663

96. Henderson DA, Shelokov A. Epidemic neuromyasthenia; clinical syndrome. N Engl J Med 1959;260(15):757-764

97. Hickie I, Davenport T, Wakefield D, et al; Dubbo Infection Outcomes Study Group. Post-infective and chronic fatigue syndromes precipitated by viral and nonviral pathogens: prospective cohort study. BMJ 2006; 333(7568):575-578

98. Vollmer-Conna U, Fazou C, Cameron B, et al. Production of pro-inflammatory cytokines correlates with the symptoms of acute sickness behaviour in humans. Psychol Med 2004;34(7):1289-1297

99. Cameron B, Bharadwaj M, Burrows J, et al; Dubbo Infection Outcomes Study. Prolonged illness after infec- tious mononucleosis is associated with altered immunity but not with increased viral load. J Infect Dis 2006; 193(5):664-671

100. Vollmer-Conna U, Cameron B, Hadzi-Pavlovic D, et al; Dubbo Infective Outcomes Study Group. Postinfective fatigue syndrome is not associated with altered cytokine production. Clin Infect Dis 2007;45(6):732-735

101. Landay AL, Jessop C, Lennette ET, Levy JA. Chronic fatigue syndrome: clinical condition associated with immune activation. Lancet 1991;338(8769):707-712

102. Patarca R, Klimas NG, Lugtendorf S, Antoni M, Fletcher MA. Dysregulated expression of tumor necrosis factor in chronic fatigue syndrome: interrelations with cellular sources and patterns of soluble immune mediator expression. Clin Infect Dis 1994;18(Suppl 1):S147-S153

103. Cannon JG, Angel J, Abad L, et al. Interleukin-1b, interleukin-1 receptor antagonist and soluble interleukin-1 receptor type II secretion in chronic fatigue syndrome. J Clin Immunol 1997;17(3):253-261

104. Swanink CM, Vercoulen JH, Galama JM, et al. Lymphocyte subsets, apoptosis, and cytokines in patients with chronic fatigue syndrome. J Infect Dis 1996;173(2):460-463

105. Bennett AL, Chao CC, Hu S, et al. Elevation of bioactive transforming growth factor-beta in serum from patients with chronic fatigue syndrome. J Clin Immunol 1997;17(2): 160-166

106. Cannon JG, Angel JB, Ball RW, Abad LW, Fagioli L, Komaroff AL. Acute phase responses and cytokine secretion in chronic fatigue syndrome. J Clin Immunol 1999;19(6): 414-421

107. Skowera A, Cleare A, Blair D, Bevis L, Wessely SC, Peakman M. High levels of type 2 cytokine-producing cells in chronic fatigue syndrome. Clin Exp Immunol 2004; 135(2):294-302

108. Broderick G, Fuite J, Kreitz A, Vernon SD, Klimas N, Fletcher MA. A formal analysis of cytokine networks in chronic fatigue syndrome. Brain Behav Immun 2010;24(7): 1209-1217

109. Caligiuri M, Murray C, Buchwald D, et al. Phenotypic and functional deficiency of natural killer cells in patients with chronic fatigue syndrome. J Immunol 1987;139(10):33063313

110. Aoki T, Usuda Y, Miyakoshi H, Tamura K, Herberman RB. Low natural killer syndrome: clinical and immunologic features. Nat Immun Cell Growth Regul 1987;6(3): $116-128$

111. Kibler R, Lucas DO, Hicks MJ, Poulos BT, Jones JF. Immune function in chronic active Epstein-Barr virus infection. J Clin Immunol 1985;5(1):46-54

112. Klimas NG, Salvato FR, Morgan R, Fletcher MA. Immunologic abnormalities in chronic fatigue syndrome. J Clin Microbiol 1990;28(6):1403-1410

113. Whiteside TL, Herberman RB. The role of natural killer cells in human disease. Clin Immunol Immunopathol 1989; 53(1):1-23

114. Suhadolnik RJ, Reichenbach NL, Hitzges $P$, et al. Upregulation of the $2-5 \mathrm{~A}$ synthetase/RNase $\mathrm{L}$ antiviral pathway associated with chronic fatigue syndrome. Clin Infect Dis 1994;18(Suppl 1):S96-S104

115. Suhadolnik RJ, Peterson DL, O'Brien K, et al. Biochemical evidence for a novel low molecular weight 2-5A-dependent $\mathrm{RNase} \mathrm{L}$ in chronic fatigue syndrome. J Interferon Cytokine Res 1997;17(7):377-385 
116. De Meirleir K, Bisbal C, Campine I, et al. A $37 \mathrm{kDa} 2-5 \mathrm{~A}$ binding protein as a potential biochemical marker for chronic fatigue syndrome. Am J Med 2000;108(2):99-105

117. Vernon SD, Unger ER, Dimulescu IM, Rajeevan M, Reeves WC. Utility of the blood for gene expression profiling and biomarker discovery in chronic fatigue syndrome. Dis Markers 2002;18(4):193-199

118. Powell R, Ren J, Lewith G, Barclay W, Holgate S, Almond J. Identification of novel expressed sequences, up-regulated in the leucocytes of chronic fatigue syndrome patients. Clin Exp Allergy 2003;33(10):1450-1456

119. Steinau M, Unger ER, Vernon SD, Jones JF, Rajeevan MS. Differential-display PCR of peripheral blood for biomarker discovery in chronic fatigue syndrome. J Mol Med (Berl) 2004;82(11):750-755

120. Kaushik N, Fear D, Richards SCM, et al. Gene expression in peripheral blood mononuclear cells from patients with chronic fatigue syndrome. J Clin Pathol 2005;58(8):826-832

121. Vernon SD, Whistler T, Aslakson E, Rajeevan M, Reeves WC. Challenges for molecular profiling of chronic fatigue syndrome. Pharmacogenomics 2006;7(2):211-218

122. Gow JW, Hagan S, Herzyk P, Cannon C, Behan PO, Chaudhuri A. A gene signature for post-infectious chronic fatigue syndrome. BMC Med Genomics 2009;2:38

123. Kuratsune H, Yamaguti K, Takahashi M, Misaki H, Tagawa S, Kitani T. Acylcarnitine deficiency in chronic fatigue syndrome. Clin Infect Dis 1994;18(Suppl 1):S62-S67

124. Plioplys AV, Plioplys S. Electron-microscopic investigation of muscle mitochondria in chronic fatigue syndrome. Neuropsychobiology 1995;32(4):175-181

125. Edwards RHT, Gibson H, Clague JE, Helliwell T. Muscle histopathology and physiology in chronic fatigue syndrome. In: Bock GR, Whelan J, eds. Chronic Fatigue Syndrome. New York: Wiley; 1993:102-131

126. Pietrangelo T, Mancinelli R, Toniolo L, et al. Transcription profile analysis of vastus lateralis muscle from patients with chronic fatigue syndrome. Int J Immunopathol Pharmacol 2009;22(3):795-807

127. Vernon SD, Whistler T, Cameron B, Hickie IB, Reeves WC, Lloyd A. Preliminary evidence of mitochondrial dysfunction associated with post-infective fatigue after acute infection with Epstein Barr Virus. BMC Infect Dis 2006; 6:15-21

128. Robinson M, Gray SR, Watson MS, et al. Plasma IL-6, its soluble receptors and $\mathrm{F} 2$-isoprostanes at rest and during exercise in chronic fatigue syndrome. Scand J Med Sci Sports 2010;20(2):282-290

129. Manuel y Keenoy B, Moorkens G, Vertommen J, De Leeuw I. Antioxidant status and lipoprotein peroxidation in chronic fatigue syndrome. Life Sci 2001;68(17):2037-2049

130. Pall ML. Elevated, sustained peroxynitrite levels as the cause of chronic fatigue syndrome. Med Hypotheses 2000; 54(1):115-125

131. Miwa K, Fujita M. Increased oxidative stress suggested by low serum vitamin $\mathrm{E}$ concentrations in patients with chronic fatigue syndrome. Int J Cardiol 2009;136(2):238-239

132. Puri BK, Agour M, Gunatilake KDR, Fernando KAC, Gurusinghe AI, Treasaden IH. An in vivo proton neurospectroscopy study of cerebral oxidative stress in myalgic encephalomyelitis (chronic fatigue syndrome). Prostaglandins Leukot Essent Fatty Acids 2009;81(5-6):303-305

133. Miwa K, Fujita M. Fluctuation of serum vitamin E (alphatocopherol) concentrations during exacerbation and remission phases in patients with chronic fatigue syndrome. Heart Vessels 2010;25(4):319-323

134. Pall ML, Satterlee JD. Elevated nitric oxide/peroxynitrite mechanism for the common etiology of multiple chemical sensitivity, chronic fatigue syndrome, and posttraumatic stress disorder. Ann N Y Acad Sci 2001;933:323-329

135. Maes M, Mihaylova I, Kubera M, Bosmans E. Not in the mind but in the cell: increased production of cyclooxygenase- 2 and inducible NO synthase in chronic fatigue syndrome. Neuroendocrinol Lett 2007;28(4):463-469

136. Maes M, Mihaylova I, Bosmans E. Not in the mind of neurasthenic lazybones but in the cell nucleus: patients with chronic fatigue syndrome have increased production of nuclear factor kappa beta. Neuroendocrinol Lett 2007;28(4): 456-462

137. Suárez A, Guillamó E, Roig T, et al. Nitric oxide metabolite production during exercise in chronic fatigue syndrome: a case-control study. J Womens Health (Larchmt) 2010;19(6): 1073-1077

138. Light AR, White AT, Hughen RW, Light KC. Moderate exercise increases expression for sensory, adrenergic, and immune genes in chronic fatigue syndrome patients but not in normal subjects. J Pain 2009;10(10):1099-1112

139. Van Oosterwijck J, Nijs J, Meeus M, et al. Pain inhibition and postexertional malaise in myalgic encephalomyelitis/ chronic fatigue syndrome: an experimental study. J Intern Med 2010;268(3):265-278

140. Manfredi AA, Rovere-Querini P. The mitochondrion-a Trojan horse that kicks off inflammation? N Engl J Med 2010;362(22):2132-2134

141. Valyi-Nagy T, Dermody TS. Role of oxidative damage in the pathogenesis of viral infections of the nervous system. Histol Histopathol 2005;20(3):957-967

142. Isaacs R. Chronic infectious mononucleosis. Blood 1948; 3(8):858-861

143. White PD, Thomas JM, Amess J, et al. Incidence, risk and prognosis of acute and chronic fatigue syndromes and psychiatric disorders after glandular fever. Br J Psychiatry 1998;173:475-481

144. Katon W, Russo J, Ashley RL, Buchwald D. Infectious mononucleosis: psychological symptoms during acute and subacute phases of illness. Gen Hosp Psychiatry 1999;21(1): 21-29

145. Jones JF, Ray CG, Minnich LL, Hicks MJ, Kibler R, Lucas DO. Evidence for active Epstein-Barr virus infection in patients with persistent, unexplained illnesses: elevated antiearly antigen antibodies. Ann Intern Med 1985;102(1):1-7

146. Straus SE, Tosato G, Armstrong G, et al. Persisting illness and fatigue in adults with evidence of Epstein-Barr virus infection. Ann Intern Med 1985;102(1):7-16

147. Salahuddin SZ, Ablashi DV, Markham PD, et al. Isolation of a new virus, HBLV, in patients with lymphoproliferative disorders. Science 1986;234(4776):596-601

148. Josephs SF, Henry B, Balachandran N, et al. HHV-6 reactivation in chronic fatigue syndrome. Lancet 1991; 337(8753):1346-1347

149. Secchiero P, Carrigan DR, Asano Y, et al. Detection of human herpesvirus 6 in plasma of children with primary infection and immunosuppressed patients by polymerase chain reaction. J Infect Dis 1995;171(2):273-280

150. Zorenzenon M, Rukh G, Botta GA, et al. Active HHV-6 infection in chronic fatigue syndrome patients from Italy: New data. J Chron Fatigue Syndr 1996;2:3-12 
151. Patnaik M, Komaroff AL, Conley E, Ojo-Amaize EA, Peter JB. Prevalence of IgM antibodies to human herpesvirus 6 early antigen $(\mathrm{p} 41 / 38)$ in patients with chronic fatigue syndrome. J Infect Dis 1995;172(5):1364-1367

152. Wagner M, Krueger GRF, Ablashi DV, Whitman JE. Chronic fatigue syndrome (CFS): a critical evaluation of testing for active human herpesvirus-6 (HHV-6) infection: review of data of 107 cases. J Chron Fatigue Syndr 1996; 2:3-16

153. Ablashi DV, Eastman HB, Owen CB, et al. Frequent HHV6 reactivation in multiple sclerosis (MS) and chronic fatigue syndrome (CFS) patients. J Clin Virol 2000;16(3):179-191

154. Nicolson GL, Gan R, Haier J. Multiple co-infections (mycoplasma, chlamydia, human herpes virus-6) in blood of chronic fatigue syndrome patients: association with signs and symptoms. APMIS 2003;111(5):557-566

155. Koelle DM, Barcy S, Huang ML, et al. Markers of viral infection in monozygotic twins discordant for chronic fatigue syndrome. Clin Infect Dis 2002;35(5):518-525

156. Reeves WC, Stamey FR, Black JB, Mawle AC, Stewart JA, Pellett PE. Human herpesviruses 6 and 7 in chronic fatigue syndrome: a case-control study. Clin Infect Dis 2000;31(1): 48-52

157. Yao K, Crawford JR, Komaroff AL, Ablashi DV, Jacobson S. Review part 2: Human herpesvirus-6 in central nervous system diseases. J Med Virol 2010;82(10):1669-1678

158. Flamand L, Gosselin J, D'Addario M, et al. Human herpesvirus 6 induces interleukin-1 beta and tumor necrosis factor alpha, but not interleukin-6, in peripheral blood mononuclear cell cultures. J Virol 1991;65(9):5105-5110

159. Enoki H, Takeda S, Matsubayashi R, Matsubayashi T. Steroid therapy in an infant with human herpesvirus 6 encephalopathy. Brain Dev 2006;28(9):597-599

160. Krueger GR, Guenther A, Knuefermann R, et al. Human herpesvirus-6 (HHV-6) in Hodgkin's disease: cellular expression of viral antigens as compared to oncogenes met and fes, tumor suppressor gene product $\mathrm{p} 53$, and interleukins 2 and 6. In Vivo 1994;8(4):501-516

161. Arena A, Capozza AB, Di Luca D. Role of IFN gamma on TNF alpha, IL-1 beta and IL-6 release during HHV-6 infection. New Microbiol 1996;19(3):183-191

162. Go T, Nakamura K. Frequent seizures with elevated interleukin-6 at the eruptive stage of exanthema subitum. Eur J Paediatr Neurol 2002;6(4):221-223

163. Silverman RH, Nguyen C, Weight CJ, Klein EA. The human retrovirus XMRV in prostate cancer and chronic fatigue syndrome. Nat Rev Urol 2010;7(7):392-402

164. Lombardi VC, Ruscetti FW, Das Gupta J, et al. Detection of an infectious retrovirus, XMRV, in blood cells of patients with chronic fatigue syndrome. Science 2009;326(5952): 585-589

165. Lo S-C, Pripuzova N, Li B, et al. Detection of MLVrelated virus gene sequences in blood of patients with chronic fatigue syndrome and healthy blood donors. Proc Natl Acad Sci U S A 2010;107(36):15874-15879

166. Henrich TJ, Li JZ, Felsenstein D, et al. Xenotropic murine leukemia virus-related virus prevalence in patients with chronic fatigue syndrome or chronic immunomodulatory conditions. J Infect Dis 2010;202(10):1478-1481

167. Knox K, Carrigan D, Simmons G, et al. No evidence of murine-like gammaretroviruses in CFS patients previously identified as XMRV-infected. Science 2011;333(6038): 94-97
168. Shin CH, Bateman L, Schlaberg R, et al. Absence of $\mathrm{XMRV}$ and other MLV-related viruses in patients with chronic fatigue syndrome. J Virol 2011;85:7195-7202

169. Cunningham L, Bowles NE, Lane RJM, Dubowitz V, Archard LC. Persistence of enteroviral RNA in chronic fatigue syndrome is associated with the abnormal production of equal amounts of positive and negative strands of enteroviral RNA. J Gen Virol 1990;71(Pt 6):1399-1402

170. Gow JW, Behan WMH, Clements GB, Woodall C, Riding $\mathrm{M}$, Behan PO. Enteroviral RNA sequences detected by polymerase chain reaction in muscle of patients with postviral fatigue syndrome. BMJ 1991;302(6778):692-696

171. Bowles NE, Bayston TA, Zhang HY, et al. Persistence of enterovirus RNA in muscle biopsy samples suggests that some cases of chronic fatigue syndrome result from a previous, inflammatory viral myopathy. J Med 1993;24(2-3): $145-160$

172. Clements GB, McGarry F, Nairn C, Galbraith DN. Detection of enterovirus-specific RNA in serum: the relationship to chronic fatigue. J Med Virol 1995;45(2):156-161

173. Richardson J. Disturbance of hypothalamic function and evidence for persistent enteroviral infection in patients with chronic fatigue syndrome. J Chron Fatigue Syndr 1995;1: 59-66

174. Soteriou B, Zhang H, Woodrow DR, Lane RJM, Archard LC. Identification of enteroviral RNA detected in muscle biopsies from patients with chronic fatigue syndrome of myositis, using reverse transcription-nested polymerase chain reaction and nucleotide sequencing. J Chron Fatigue Syndr 1996;2:74-75

175. Gow JW, Behan WMH, Cash P, et al. Enteroviral replication and chronic fatigue syndrome. J Chron Fatigue Syndr 1996;2:86

176. Chia JKS, Chia AY. Chronic fatigue syndrome is associated with chronic enterovirus infection of the stomach. J Clin Pathol 2008;61(1):43-48

177. Swanink CMA, Melchers WJG, van der Meer JWM, et al. Enteroviruses and the chronic fatigue syndrome. Clin Infect Dis 1994;19(5):860-864

178. Lindh G, Samuelson A, Hedlund KO, Evengård B, Lindquist L, Ehrnst A. No findings of enteroviruses in Swedish patients with chronic fatigue syndrome. Scand J Infect Dis 1996;28(3):305-307

179. Kerr JR, Bracewell J, Laing I, et al. Chronic fatigue syndrome and arthralgia following parvovirus B19 infection. J Rheumatol 2002;29(3):595-602

180. Kerr JR, Barah F, Mattey DL, et al. Circulating tumour necrosis factor-alpha and interferon-gamma are detectable during acute and convalescent parvovirus B19 infection and are associated with prolonged and chronic fatigue. J Gen Virol 2001;82(Pt 12):3011-3019

181. Matano S, Kinoshita H, Tanigawa K, Terahata S, Sugimoto T. Acute parvovirus B19 infection mimicking chronic fatigue syndrome. Intern Med 2003;42(9):903-905

182. Kerr JR, Gough J, Richards SCM, et al. Antibody to parvovirus B19 nonstructural protein is associated with chronic arthralgia in patients with chronic fatigue syndrome/myalgic encephalomyelitis. J Gen Virol 2010;91(Pt 4):893-897

183. Coyle PK, Krupp L. Borrelia burgdorferi infection in the chronic fatigue syndrome. Ann Neurol 1990;28:243-244

184. Sigal LH. Summary of the first 100 patients seen at a Lyme disease referral center. Am J Med 1990;88(6):577-581 
185. Pollark RJ, Komaroff AL, Telford SR III, et al. Borrelia burgdorferi infection is rarely found in patients with chronic fatigue syndrome. Clin Infect Dis 1995;20(2):467-468

186. Wildman MJ, Smith EG, Groves J, Beattie JM, Caul EO, Ayres JG. Chronic fatigue following infection by Coxiella burnetii (Q fever): ten-year follow-up of the 1989 UK outbreak cohort. QJM 2002;95(8):527-538

187. Marmion BP, Sukocheva O, Storm PA, et al. Q fever: persistence of antigenic non-viable cell residues of Coxiella burnetii in the host-implications for post $\mathrm{Q}$ fever infection fatigue syndrome and other chronic sequelae. QJM 2009; 102(10):673-684

188. Penttila IA, Harris RJ, Storm P, Haynes D, Worswick DA, Marmion BP. Cytokine dysregulation in the post-Q-fever fatigue syndrome. QJM 1998;91(8):549-560

189. Schluederberg A, Straus SE, Peterson P, et al. NIH conference. Chronic fatigue syndrome research. Definition and medical outcome assessment. Ann Intern Med 1992; 117(4):325-331

190. Bates DW, Buchwald D, Lee J, et al. Clinical laboratory test findings in patients with chronic fatigue syndrome. Arch Intern Med 1995;155(1):97-103

191. Chaudhuri A, Behan PO. Fatigue in neurological disorders. Lancet 2004;363(9413):978-988

192. Fox MD, Greicius M. Clinical applications of resting state functional connectivity. Front Syst Neurosci 2010;4:19

193. Wunder A, Klohs J, Dirnagl U. Non-invasive visualization of CNS inflammation with nuclear and optical imaging. Neuroscience 2009;158(3):1161-1173

194. de Backer ME, Nabuurs RJ, van Buchem MA, van der Weerd L. MR-based molecular imaging of the brain: the next frontier. AJNR Am J Neuroradiol 2010;31(9):1577-1583

195. Modo M, Bulte JW. From molecules to man: the dawn of a vitreous man. Methods Mol Biol 2011;711:3-14 